agriTECH, 41 (4) 2021, 362-375

\title{
Effect of Rotten Butter Shock Load on Anaerobic Digestion of Chicken Manure
}

\author{
Gaweł Sołowski ${ }^{1 *}$, Izabela Konkol ${ }^{1}$, Marwa Shalaby ${ }^{2}$ \\ ${ }^{1}$ Institute of Fluid-Flow Machinery of Polish Academy of Sciences, Gdańsk Poland \\ ${ }^{2}$ National Research Centre-Chemical Engineering \& Pilot Plant Department- Engineering Division \\ ${ }^{*}$ Corresponding author: Gaweł Sołowski, Email: gsolowski@imp.gda.pl
}

Submission: June 10, 2020; Revision: August 16, 2020, November 21, 2020; Acceptance: December 2, 2020

\begin{abstract}
Anaerobic digestion is a popular method for improving fertilizing properties, but there is no report on the effect of shock load with butter on anaerobic digestion of chicken manure. Therefore, this study aimed to investigate the anaerobic digestion of chicken manure with butter addition. The volatile suspended solid (VSS) was set at $20 \mathrm{~g}$ VSS/L with different butter additions from 0 to $60 \mathrm{~g}$ VSS/L and different oxygen flow rate (OFR) from 0 to $2.5 \mathrm{~mL} / \mathrm{h}$. The results showed that ammonia ranged from $0.072 \mathrm{~g} / \mathrm{L}$ to $0.082 \mathrm{~g} / \mathrm{L}$, while the volatile acids ranged from $425 \mathrm{mg} / \mathrm{L}$ to $325 \mathrm{mg} / \mathrm{L}$. The volatile organic acid was significantly influenced by a change in OFR compared to ammonia, while a correlation between hydrogen and hydrogen sulfide was observed. The results showed that the highest hydrogen and methane production was obtained at butter addition of $30 \mathrm{~g} \mathrm{VSS} / \mathrm{L}$ with OFR $1.4 \mathrm{~mL} / \mathrm{h}$ with volumes of $78 \mathrm{~mL}$ and $25 \mathrm{~L}$ respectively. In addition, hydrogen sulfide emissions induced rapid growth with increase in butter concentration.
\end{abstract}

Keywords: Anaerobic digestion; butter; chicken manure; dark fermentation

\section{INTRODUCTION}

The annual chicken manure production in Poland is approximately $105.5 \times 10^{6} \mathrm{Mg}$ (Domaszewicz et al., 2016), and represents a large part of wastes, which needs proper utilization and management for reuse. Chicken manure is rich in ammonia and water content (Suchowska-Kisielewicz, 2016), it is denser compared to cow dung and therefore possesses more volatile acids and phosphate. Meanwhile, anaerobic digestion (AD) of chicken manure has great potential as an economical substrate compared to pig manure. Pig breeding apart from meat yields no profits (Theuerl et al., 2019), conversely, poultry also produces eggs (from living), which is remarkable when methane production is not profitable enough (Fagbohungbe et al., 2019). Furthermore, Alfa et al. (2014), reported that chicken manure produces less biogas than cow dung but more than lemongrass, hence, it is a potential source of methane and hydrogen but is inhibited by large volumes of ammonia in the anaerobic digestion (AD) process (Alsouleman et al., 2016;). Chicken manure is usually pretreated by the bird gastric system with other plant grains and insects (Chodová \& Tůmová, 2020), meanwhile, anaerobic digestion is a popular method for improving its fertilizing properties (Ogundijo et al., 2017). Billen et al. (2015) proposed an approach for the production of electricity from manure and the several methods involved include dilution of water chemicals and thermal reduction of ammonia. Also, Lami et al. (2016) tested the thermal and alkaline $(\mathrm{CaO})$ pretreatment of chicken manure mixed with orange peels in ratio $3: 1$ and obtained up to $75 \%$ thermal pretreatment reduction of the substrate and $1091.67 \mathrm{~mL}$ of biogas at $80{ }^{\circ} \mathrm{C}$ 
while the $\mathrm{CaO}$ pretreatment obtained $1124 \mathrm{~mL}$ biogas. Anjumet et al. (2016) used thermal treatment at $60^{\circ} \mathrm{C}$, while Janczak et al. (2017) added biochar to reduce ammonia emissions. Furthermore, Abouleinen et al. (2009) found that a high level of ammonia ranging from $8 \mathrm{~g}^{-\mathrm{N}} \mathrm{kg}^{-1} \mathrm{CM}$ to $14 \mathrm{~g}^{-\mathrm{N}} \mathrm{kg}^{-1} \mathrm{CM}$ did not interfere with the anaerobic digestion process. In the dark fermentation (DF), fat as glycerol is considered as a material that has great potential to produce hydrogen (Słupek et al., 2019), but with particularly isolated bacteria (Trchounian \& Trchounian, 2015). Ammonia emission and shifting process to basic conditions block the potential of chicken manure to produce hydrogen by DF in the acidophilic process (Tang et al., 2008). Another modification is the use of shock load for enhancing biogas production, meanwhile, food wastes industries produce fats as a kind of wastes, when fat wastes are provided into the sewage waste biogas plants, there is an immense problem of foaming. However, there are no previous reports on the effect of shock load with butter for chicken manure. The butter is an example of daily fat wastes, that often becomes rancid and is easily wasted due to the short expiry date and regular overproduction. The fats digestion usually reaches high efficiency through AD (García and Cammarota, 2019). Therefore, there is a need to determine the mixture of substrates related to fats and $A D$ availability. Fat wastes have been reportedly improved in a ratio of 1:8 digestion of cow manure (Sandriaty et al., 2018). Bacteria (also shock load) usually inhibit methane production (Bundhoo et al., 2015). Another problem with the process is hydrogen sulfide emission, specifically for chicken manure (Khoshnevisan et al., 2017). However, there are no reported dependencies on hydrogen sulfide with other gases present in biogas plants. The observance of biogas components dependence is crucial to eliminate or limit hydrogen sulfide emission. A study examined butter addition as a stressing agent by shock-loading in wheat straw (Kaparaju et al., 2009). There is a need to also consider the effect of micro-aeration on the mixed substrate, similar to monosubstrate (Sołowski et al., 2019) given that it is beneficial for anaerobic digestion (Pokorna-Krayzelova et al., 2018), and dark fermentation (Sołowski et al., 2019). However, there are no reports on the influence of micro-aeration on denitrification. Volatile acid control by micro-aeration had been carried out on monosubstrate (Nguyen and Khanal, 2018). Therefore, there is a need to determine the effect of the mixture either towards $A D$ predominantly or rather to $D F$. In this study, the relationships between microaeration with $A D$ to denitrification and volatile acid reduction were tested. Meanwhile, volatile acids are byproducts that increase the profitability of biogas plants (Atasoy and Cetecioglu, 2020), and are easily formed in dark fermentation compared to anaerobic digestion (Hitit et al., 2017). This study also aims to identify when the shock load shifts the process for hydrogen or methane production digestion. In addition, it compared the influence of vegetal fat (butter) addition from $10 \mathrm{~g}$ VSS/L to $60 \mathrm{~g}$ VSS/L on chicken manure concentration of $20 \mathrm{~g} \mathrm{VSS} / \mathrm{L}$ to the anaerobic digestion process.

\section{MATERIALS AND METHODS}

\section{Materials}

The inoculum was collected from an agriculture biogas plant in a mesophilic range of temperature, mainly on maize silage, stored for about two weeks to minimize biogas production, and sieved before use to remove large particles.

The chicken manure was collected from one of the broiler poultry farms located in the Pomeranian district, Poland. The bedding for poultry farming was wheat straw and the broilers were fed with corn seeds. After the collection, the substrate was stored at $-18{ }^{\circ} \mathrm{C}$, kept at ambient temperature a day before the experiment, and was then applied for methane fermentation.

Table 1. Characteristics of inoculum and substrates

\begin{tabular}{lccc}
\hline \multicolumn{1}{c}{ Material } & $\mathrm{pH}$ & $\mathrm{TS}[\% \mathrm{FM}]$ & $\mathrm{VSS}[\% T S]$ \\
\hline Inoculum & 8.2 & $1.09 \pm 0.03$ & $45.35 \pm 1.03$ \\
Chicken manure $20 \mathrm{~g}$ VSS/L & 7.8 & $3.10 \pm 0.03$ & $51.00 \pm 1.06$ \\
Chicken manure $20 \mathrm{~g}$ VSS/L and $10 \mathrm{~g} \mathrm{VSS} / \mathrm{L}$ of butter & 7.9 & $2.60 \pm 0.02$ & $47.00 \pm 1.20$ \\
Chicken manure $20 \mathrm{~g} \mathrm{VSS} / \mathrm{L}$ and $20 \mathrm{~g} \mathrm{VSS} / \mathrm{L}$ of butter & 7.8 & $2.70 \pm 0.02$ & $49.00 \pm 1.11$ \\
Chicken manure $20 \mathrm{~g}$ VSS/L and $30 \mathrm{~g}$ VSS/L of butter & 7.8 & $3.4 \pm 0.02$ & $51.20 \pm 1.03$ \\
Chicken manure $20 \mathrm{~g}$ VSS/L and $40 \mathrm{~g}$ VSS/L of butter & 7.83 & $5.7 \pm 0.02$ & $53.00 \pm 1.11$ \\
Chicken manure $20 \mathrm{~g}$ VSS/L and $45 \mathrm{~g}$ VSS/L of butter & 7.8 & $1.8 \pm 0.02$ & $47.00 \pm 1.14$ \\
Chicken manure $20 \mathrm{~g}$ VSS/L and $60 \mathrm{~g}$ VSS/L of butter & 7.9 & $5.7 \pm 0.02$ & $52.00 \pm 1.11$ \\
\hline
\end{tabular}


The fat used was rotten butter from the restaurant '3 Smaki' in Gdańsk with concentrations from 0 to 60 $\mathrm{g}$ VSS/L added with $20 \mathrm{~g}$ VSS/L of manure as shown in table 1 . The samples were centrifuged $(5000 \mathrm{rpm}$ for 10 minutes) to separate liquid and solid phase. A solid fraction of pretreated chicken manure (P-CM) was employed during experiments.

The amount of fresh matter (FM) for the inoculum and substrate total solids (TS) [\%FM] and volatile solids (VSS) [\%TS] were determined according to Standard Methods (Moriarty, 2013;) (Table 1).

Measurements for each substrate and inoculum are needed to determine the right amounts of VTS in each fermentor and biogas efficiency production of the substrates in the units $\mathrm{m}^{3} / \mathrm{Mg} \mathrm{FM}, \mathrm{TS}$, and VSS.Ammonia cuvette tests (Hach, UK) were used to determine $\mathrm{mg} \mathrm{NH}_{4}^{-}$ $\mathrm{N} / \mathrm{L}$, meanwhile, samples of liquids were filtered before the analyses with $0.45 \mu \mathrm{m}$ membrane syringe-filter (Pureland). The error of measurement was $\pm 0.01 \mathrm{~mL}$

To determine the concentration of volatile organic acid, the FOS Nordmann-method was used (Nordmann, 1977). $100 \mathrm{~mL}$ of the sample was centrifuged (5000 rpm for 10 minutes) and. $20 \mathrm{~mL}$ of supernatant was titrated to $\mathrm{pH}=4.4$ (FOS) with sulfuric acid (0.1 M) (Chemland, 98\%) with continuous stirring. The error of measurement was $\pm 0.01 \mathrm{~mL}$.

\section{Equipment}

The experiments were carried out in the Laboratory of Biomass Energy Transformation at the Szewalski Institute of Fluid-Flow Machinery, Polish Academy of Science in Gdańsk (Poland), while the procedures were performed according to the NREL norms for biogas production (Moriarty, 2013). Methane fermentations were carried out in $2000 \mathrm{~mL}$ glass reactors with a working load of $1200 \mathrm{~mL}$ and the tested substrates were placed in the reactors with inoculum. After closing, the reactors were purged with nitrogen for 5 minutes to remove oxygen and then micro-aerated twice per day using a syringe of $25 \mathrm{~mL}$ volume with error \pm 0.1 $\mathrm{mL}$ and pressure of $1.29 \mathrm{~atm}$, while the oxygen flow rates (OFR) ranged between $0 \mathrm{~mL} / \mathrm{h}$ to $2.5 \mathrm{~mL} / \mathrm{h}$, Furthermore, the reactors were placed in a water bath with a temperature of $38 \pm 2^{\circ} \mathrm{C}$ to create appropriate conditions for mesophilic fermentation with a $\mathrm{pH}$ between 8.1 and 8.3 adjusted by solution of $0.1 \mathrm{M} \mathrm{HCl}$ (Chemland, 34\%), and 0.1M NaOH (Chemland 100\%). The process temperature was established at $38^{\circ} \mathrm{C}$ in line with the Darżyno plant and some glycerol fermentations (Toledo-Alarcónet al., 2017). The biogas was collected in each digester in a cylindrical vessel filled with barrier liquid to prevent solubility. This system works on the principle of connected vessels, meanwhile, all the

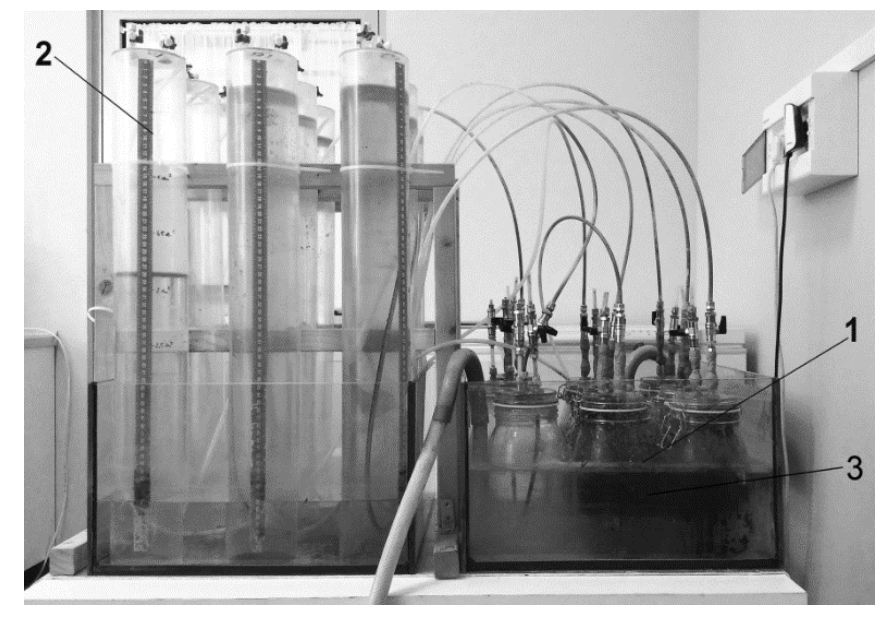

Figure 1. Fermentation set-up used in the experiment: 1. glass reactors, 2 . cylindrical vessel for collecting biogas, 3 . water bath chamber under mesophilic conditions $\left(38 \pm 2{ }^{\circ} \mathrm{C}\right)$

experiments were implemented in triplicate and the setup is shown in Figure 1.

Batch experiments were continued until daily biogas production was less than $1 \%$ of the total. Furthermore, volumes of measured biogas were normalized to standard conditions ( $0^{\circ}$ Cand 1.013 bar) using Equation (1) where: $V_{s}$ is the volume of measured gas at standard temperature and pressure, $V_{m}$ is the volume of measured gas at ambient conditions, $T_{m}^{m}$ is ambient temperature, $T_{s}$ is a standard temperature, and $\mathrm{P}_{\mathrm{s}}$ is standard pressure.

$\mathrm{V}_{\mathrm{s}}=\frac{\mathrm{V}_{\mathrm{m}} \cdot \mathrm{T}_{\mathrm{s}} \cdot \mathrm{P}_{\mathrm{m}}}{\mathrm{T}_{\mathrm{m}} \cdot \mathrm{P}_{\mathrm{s}}}$

The qualitative and quantitative assessments of the gases were performed in two stages. First, the gas was assessed using a portable biogas analyzer (GA5000, Geotech), with a minimum volume of 0.45 $\mathrm{dm}^{3}$. The analyzer used was ATEXII2G Ex ib IIAT1 Gb $\left(\mathrm{Ta}=-10^{\circ} \mathrm{C}\right.$ to $\left.+50^{\circ} \mathrm{C}\right)$, IECEx, CSA quality, and UKAS ISO 17025 calibration certificate. Biogas measurements were carried out every day at the same time with an accuracy of $\pm 0.0001 \mathrm{dm}^{3}$. The equipment was used to measure $\mathrm{CH}_{4}, \mathrm{CO}_{2}, \mathrm{O}_{2}, \mathrm{H}_{2}$ and $\mathrm{H}_{2} \mathrm{~S}$ in the ranges of $0-100 \%, 0-100 \%, 0-25 \%, 0-1000$ ppm, and 0-5000 ppm, respectively. Meanwhile, during the second stage, when hydrogen concentration was above 1000 ppm, the gas was assessed using a gas chromatograph (GC) GC SRI 8060, with a thermal conductivity detector (SRI) and argon as a carrier (gas flow rate was $0.6 \mathrm{~mL} / \mathrm{h}$ ). A Silco packed column Restek ${ }^{\circledR}$ with characteristics of $2 \mathrm{~m} / 2 \mathrm{~mm}$ ID $1 / 8^{\prime \prime}$ OD Silica was used, while the detector temperature ranged between $46^{\circ} \mathrm{C}$ and 196 ${ }^{\circ} \mathrm{C}$. Furthermore, the oven was set at a temperature of $23{ }^{\circ} \mathrm{C}$ to $200{ }^{\circ} \mathrm{C}$, while the injection temperature 


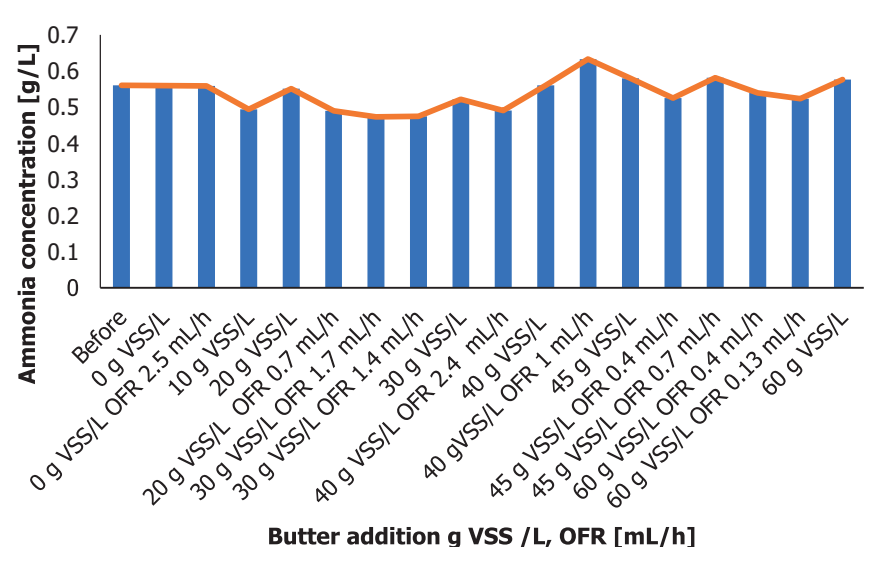

Figure 2. Ammonia concentration before fermentation and after fermentation at different concentrations of butter and micro-aeration rates

(splitless mode) was $45^{\circ} \mathrm{C}$. Calibrations of the devices were performed twice a week, meanwhile, oxygen and nitrogen were assumed as ballast gases and were not considered as biogas.

\section{RESULT AND DISCUSSION}

\section{Ammonia Production}

Figure 3 shows that the ammonia change between butter addition from $0 \mathrm{~g}$ VSS/L and $60 \mathrm{~g}$ VSS/L were significant, but minimal in $0 \mathrm{~g} \mathrm{VSS} / \mathrm{L}$ and OFR $0 \mathrm{~mL} / \mathrm{h}$, while two times higher decrease was found at OFR 2.5 $\mathrm{mL} / \mathrm{h}$. Furthermore, a reduction was observed in the range of butter addition from $0 \mathrm{~g}$ VSS/L to $40 \mathrm{~g} \mathrm{VSS} / \mathrm{L}$. From this concentration, ammonia reduction or increase depended on micro-aeration, for the butter concentration of $20 \mathrm{~g} \mathrm{VSS} / \mathrm{L}$ to $30 \mathrm{~g} \mathrm{VSS} / \mathrm{L}$, microaeration improved denitrification, meanwhile, anaerobic conditions were better at $40 \mathrm{~g} \mathrm{VSS} / \mathrm{L}$ compared to OFR $2.4 \mathrm{~mL} / \mathrm{h}$ microaeration. In the $40 \mathrm{~g} \mathrm{VSS} / \mathrm{L}$ butter and OFR $1 \mathrm{~mL} / \mathrm{h}$ treatment, there was a significant increase in ammonia, meanwhile, for $45 \mathrm{~g} \mathrm{VSS} / \mathrm{L}$ butter, only OFR $0.4 \mathrm{~mL} / \mathrm{h}$ caused a reduction of ammonia. In contrast, for butter addition of $60 \mathrm{~g} \mathrm{VSS} / \mathrm{L}$, microaeration improved reduction while anaerobic condition caused an increase. The butter addition $10 \mathrm{~g} \mathrm{VSS} / \mathrm{L}$ to $30 \mathrm{~g} \mathrm{VSS} / \mathrm{L}$ in this study was more efficient compared to (Budych-Gorzna et al., 2016).

\section{Volatile Organic Acids}

The volatile acid reduction which occurred in the range of butter addition of $20 \mathrm{~g} \mathrm{VSS} / \mathrm{L}$ with OFR $0.7 \mathrm{~mL} / \mathrm{h}$ up to $40 \mathrm{~g}$ VSS/L was strictly anaerobic. Similarly, $60 \mathrm{~g}$ VSS/L under microaerated conditions decreased volatile organic acid, while anaerobic conditions increased this

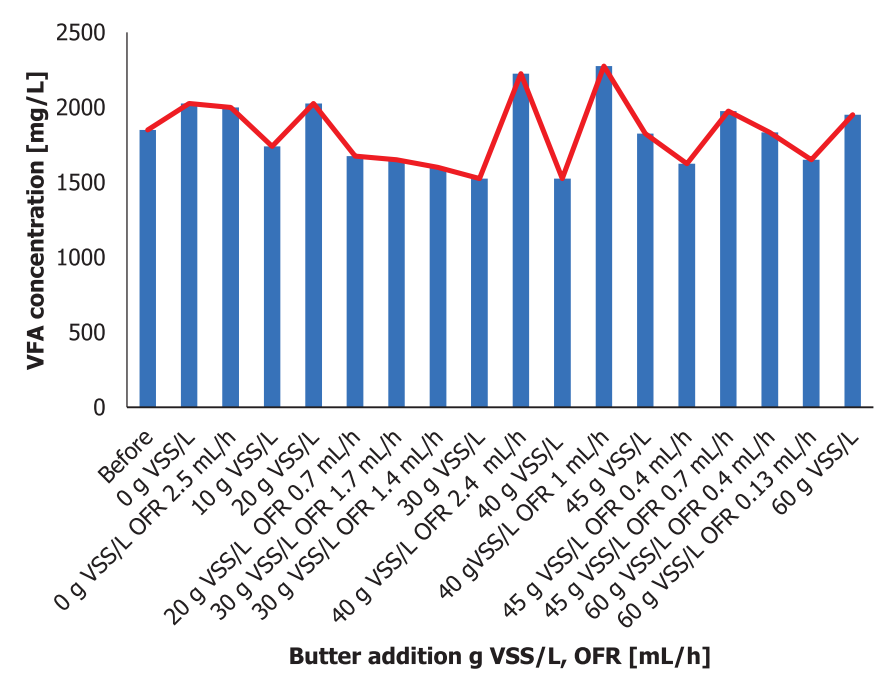

Figure 3. Volatile fatty acids (VFA) concentration before and after fermentation at different concentrations of butter and micro-aeration rates

value. In the strictly anaerobic conditions with $60 \mathrm{~g}$ VSS/L, $45 \mathrm{~g} \mathrm{VSS} / \mathrm{L}$, and $20 \mathrm{~g} \mathrm{VSS} / \mathrm{L}$, the volatile acid concentration increased, but there was a reduction in the $10 \mathrm{~g} / \mathrm{L}$. Furthermore, in the other strictly anaerobic cases (OFR $0 \mathrm{~mL} / \mathrm{h}$ ), the concentration of volatile acids decreased. Therefore, the increase or decrease in VOC depends on micro-aeration and the mass of added butter. The most significant concentration of volatile organic acids adjustment (butyric, propionic, and acetic acids) occurred at $40 \mathrm{~g}$ VSS/L. These findings in line with dark fermentation reports suggest a significant increase in hydrogen production (Dreschke et al., 2018). However, Figure 4 with 9 show that the results obtained were not consistent with the principal rule. With butter addition of $30 \mathrm{~g} \mathrm{VSS} / \mathrm{L}$, micro-aeration increased, while volatile acid concentration decreased, meanwhile, hydrogen production was higher in OFR $1.4 \mathrm{~mL} / \mathrm{h}$ compared to 1.7 $\mathrm{mL} / \mathrm{h}$. This shows that micro-aeration decreased volatile acids production in higher range of OFR compared to hydrogen production. Therefore, it is a control parameter in the case of organic acid production such as in butyric acid fermentation (Atasoy et al., 2018).

\section{Methane Production}

The differences between methane productions from $0 \mathrm{~g} \mathrm{VSS} / \mathrm{L}$ to $60 \mathrm{~g} \mathrm{VSS} / \mathrm{L}$ were significant as indicated by Figures $4 \mathrm{~A}$ and $4 \mathrm{~B}$ which show accumulated methane volumes up to $3.7 \mathrm{~L}$. Microaeration correlated with an increase in the growth of initial concentration and enhanced accumulated methane production as observed in samples of 0 to $40 \mathrm{~g} \mathrm{VSS} / \mathrm{L}$ in line with a previous study (Sołowski et al., 2020). The limiting load of butter, 


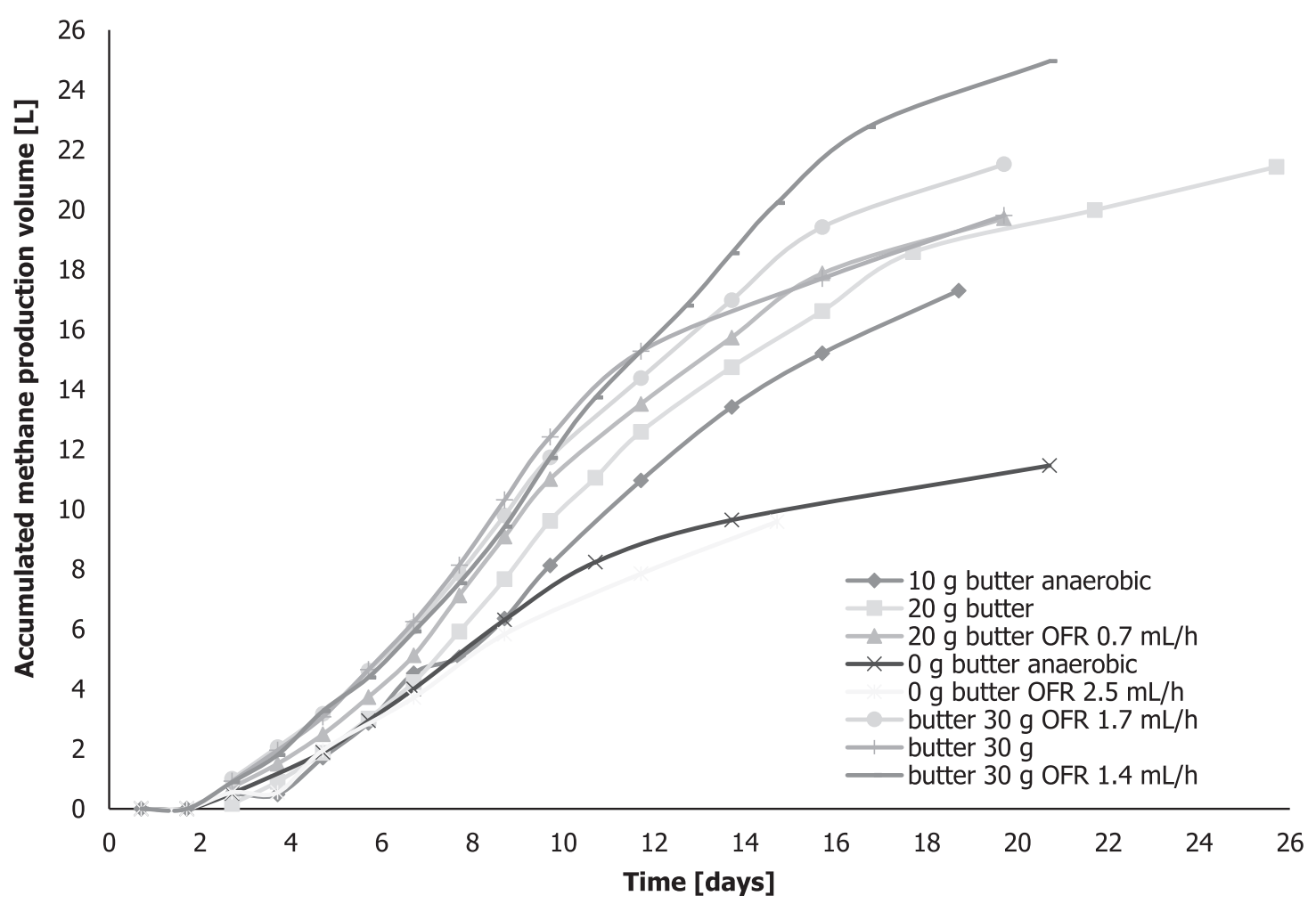

Figure 4A. Accumulated methane production from chicken manure of $20 \mathrm{~g} \mathrm{VSS} / \mathrm{L}$ from different butter loads $\mathrm{g}$ VSS/L and oxygen flow rates

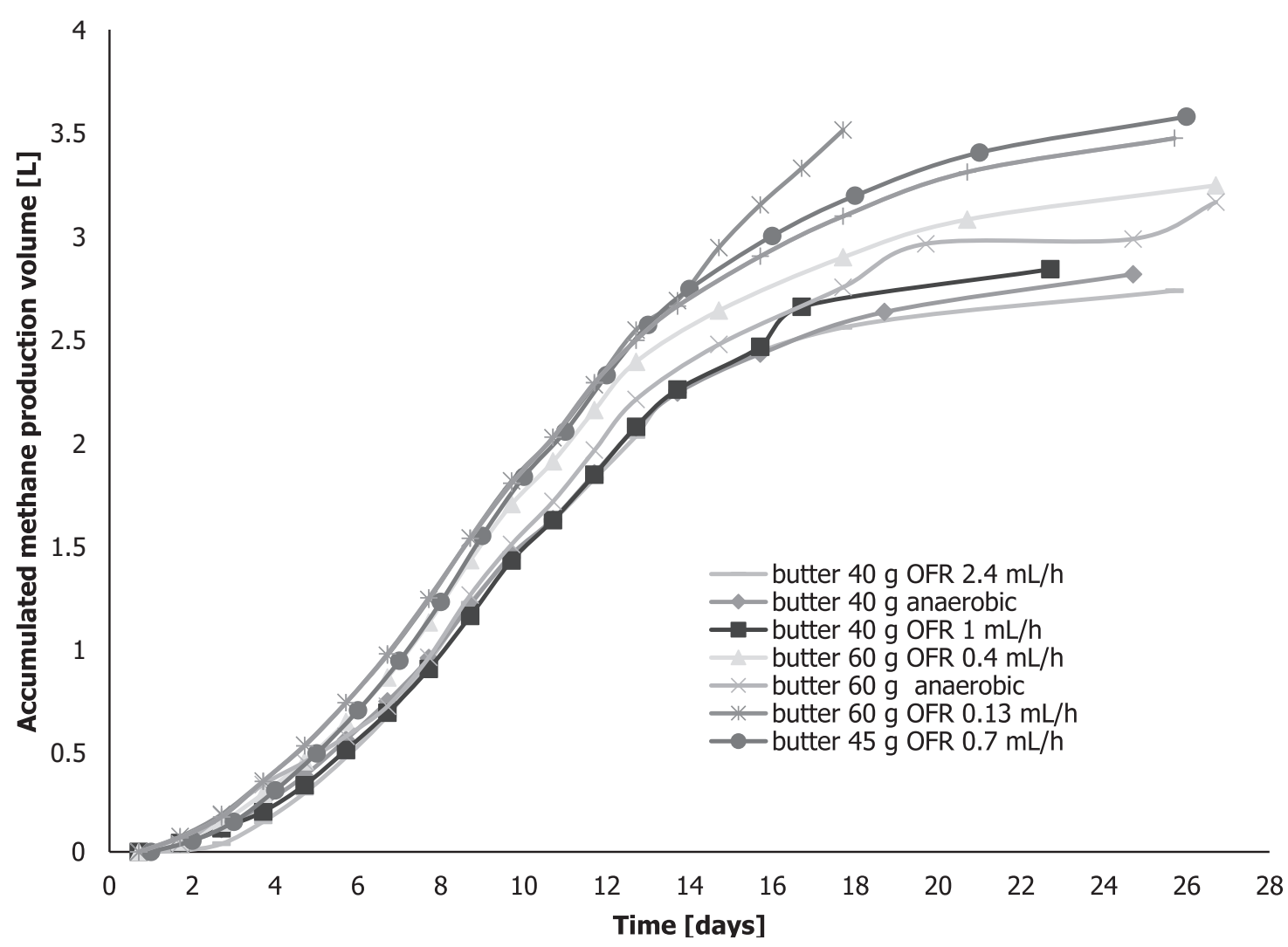

Figure 4B. Accumulated methane production from chicken manure of $20 \mathrm{~g} \mathrm{VSS} / \mathrm{L}$ from different butter loads g VSS/L and oxygen flow rates 


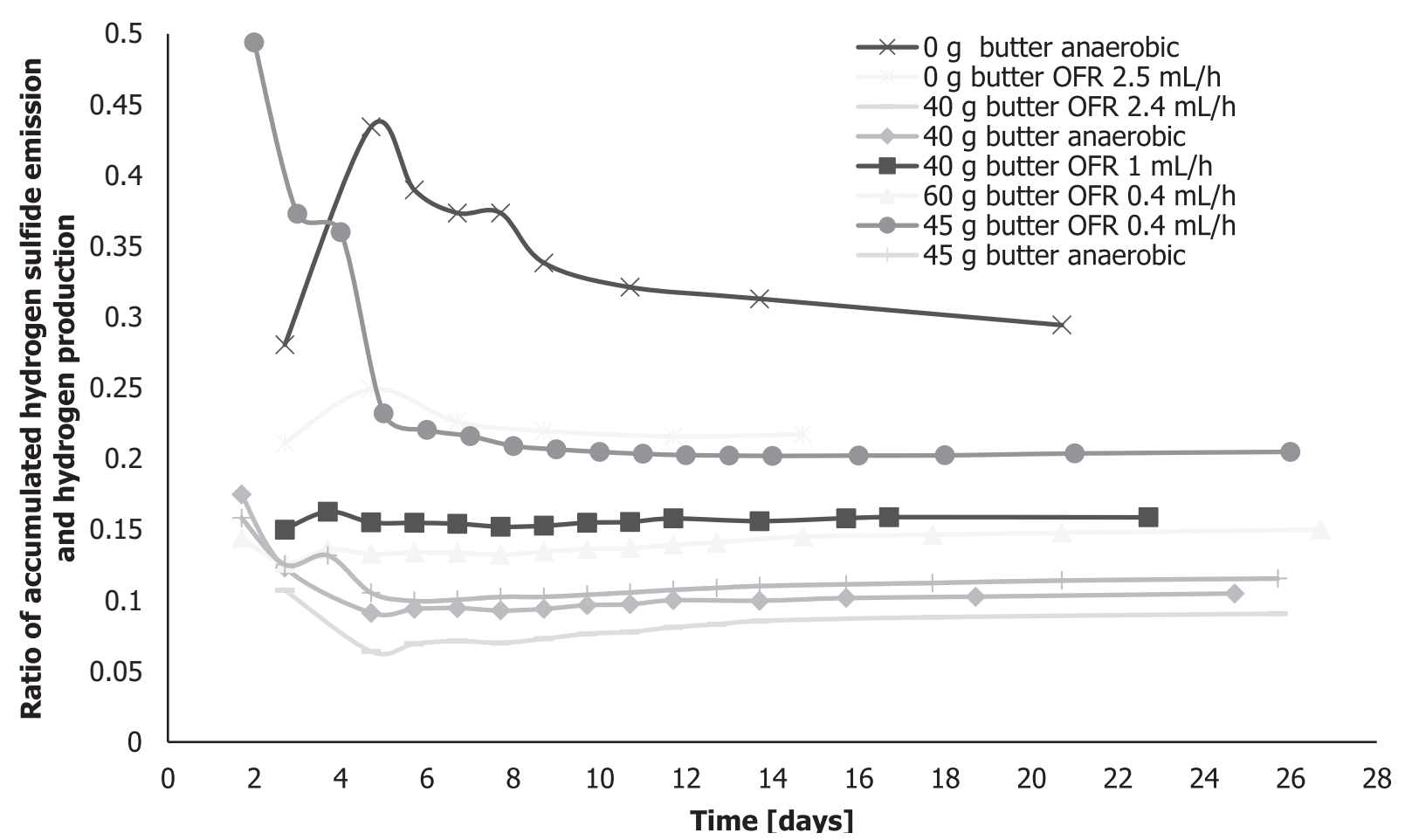

Figure 5A. The ratio of accumulated hydrogen sulfide emission and hydrogen production from chicken manure at different butter loads and oxygen flow rates

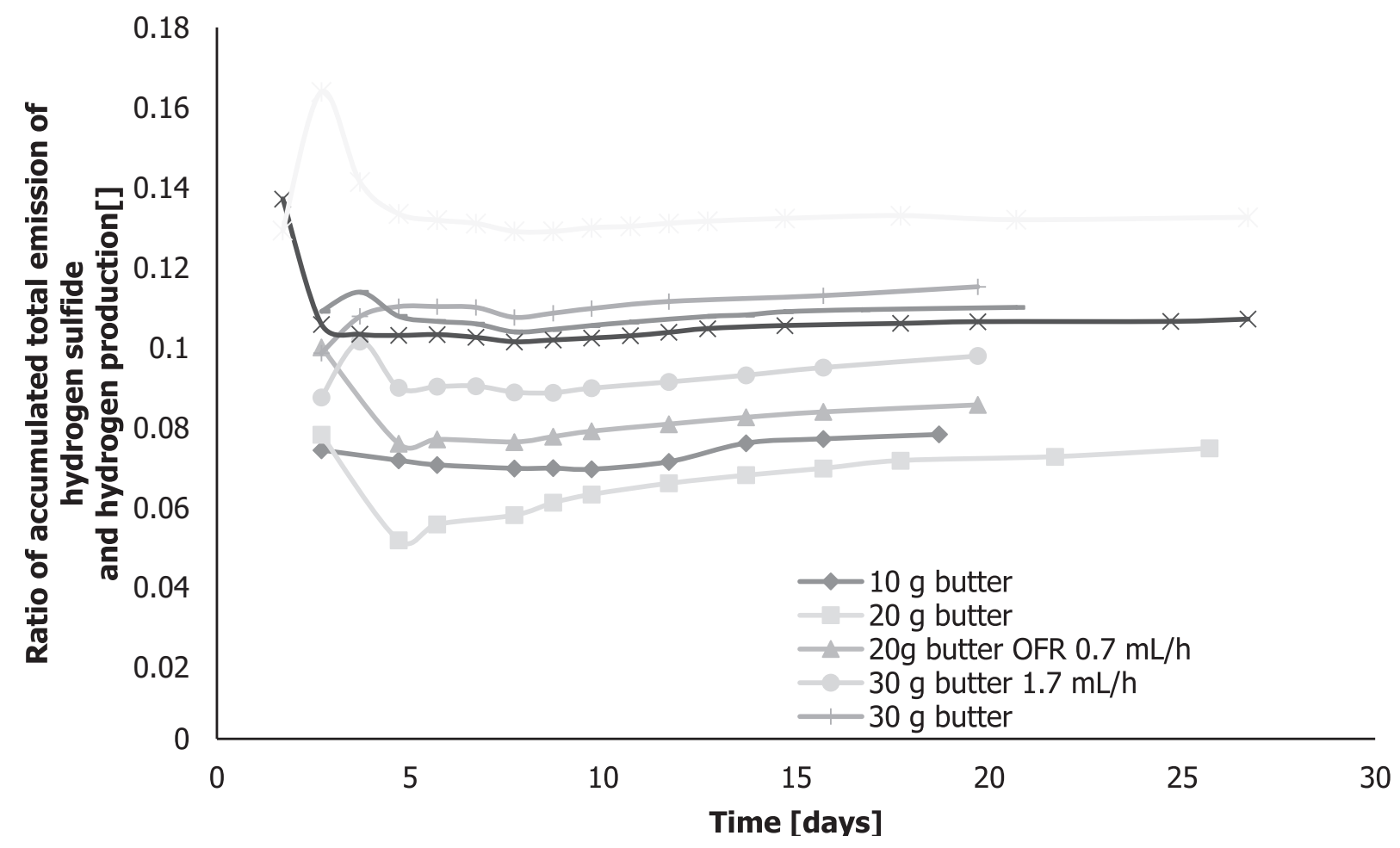

Figure 5B. The ratio of accumulated total emission of hydrogen sulfide and hydrogen production from chicken manure at different butter loads and oxygen flow rates 


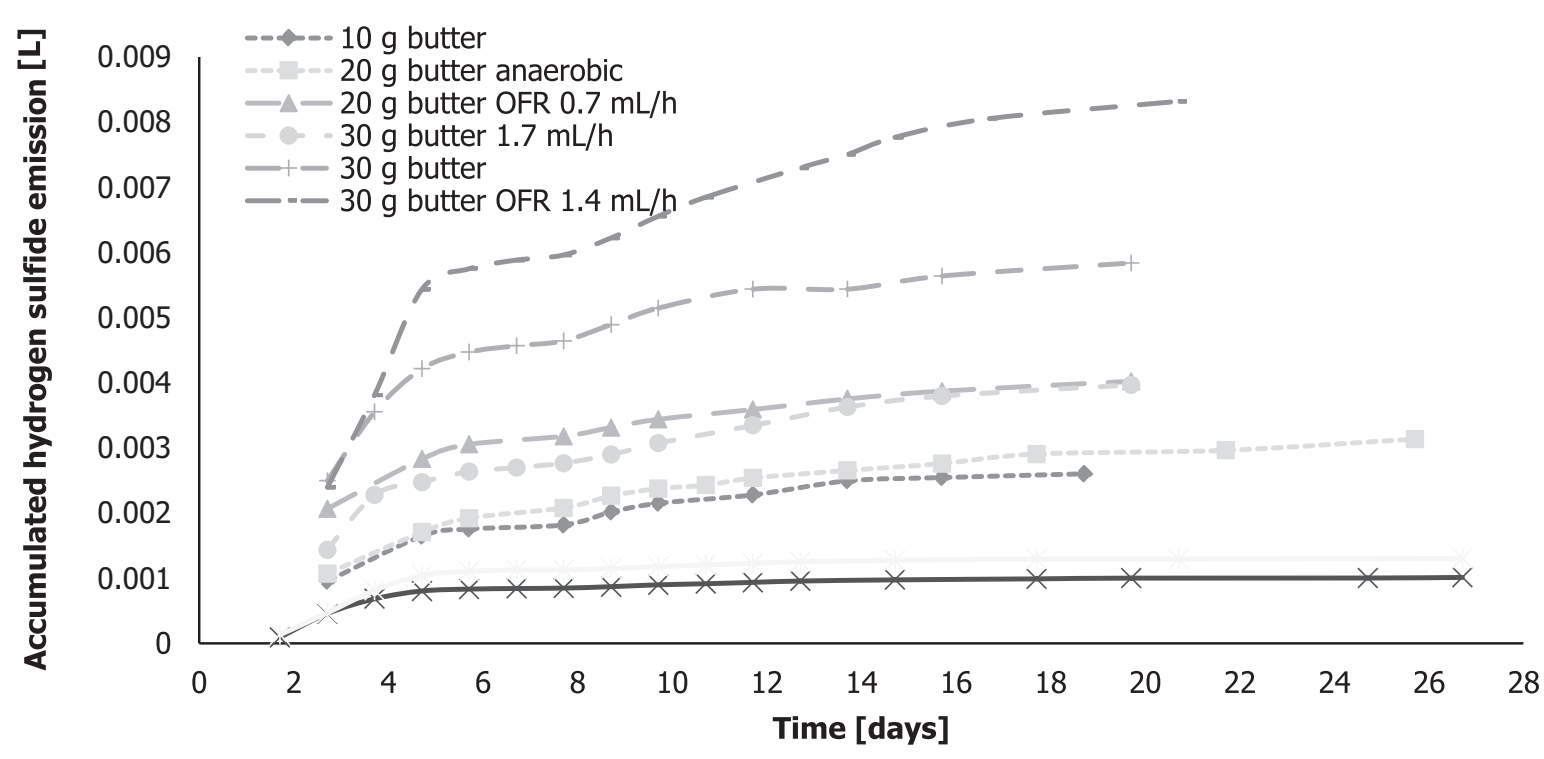

Figure 6A. Accumulated hydrogen sulfide emission from chicken manure different butter loads and oxygen flow rates

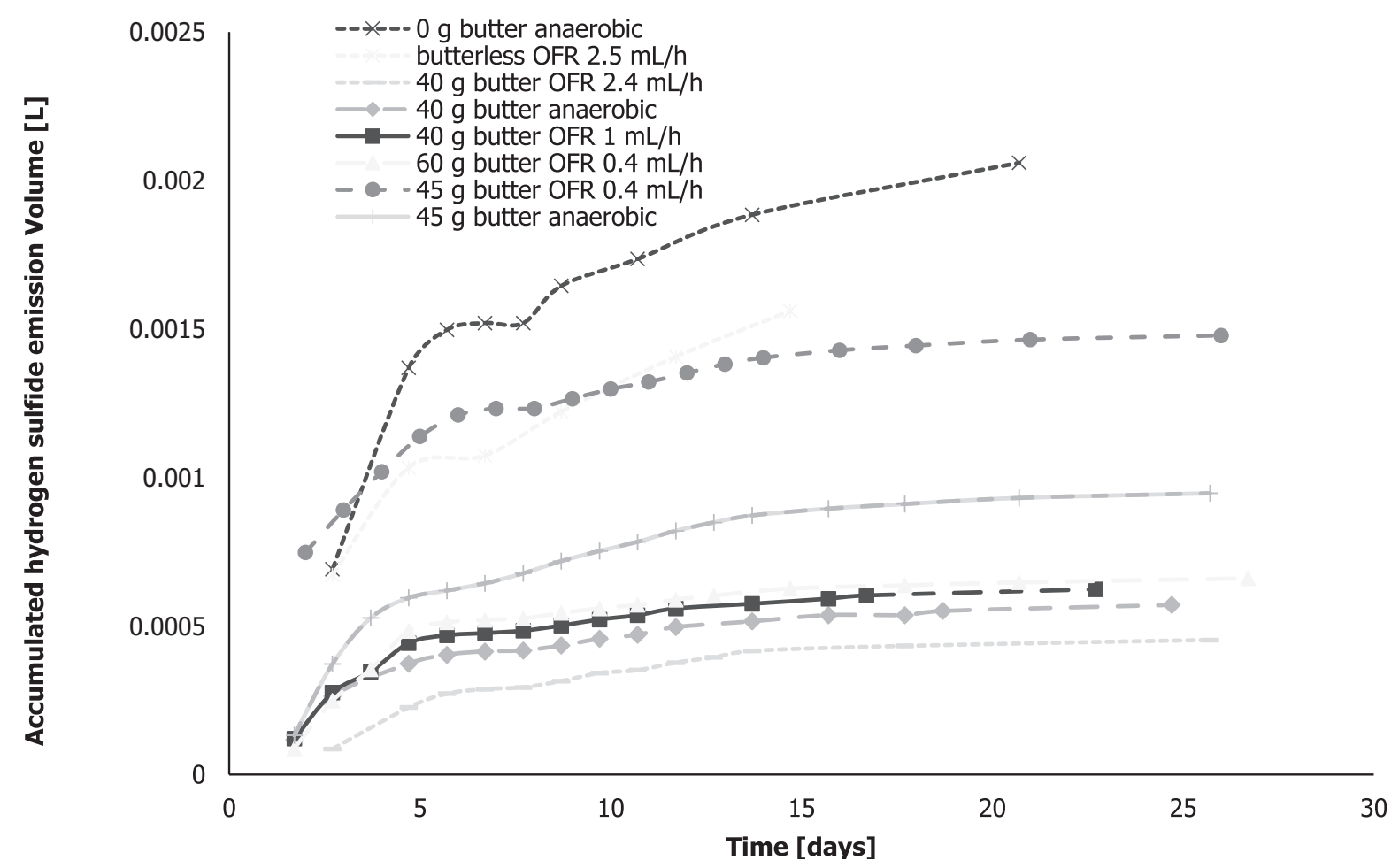

Figure $6 \mathrm{~B}$. Accumulated hydrogen sulfide emission from chicken manure of $20 \mathrm{~g} \mathrm{VSS} / \mathrm{L}$ at different butter loads $\mathrm{g}$ VSS/L and oxygen flow rates.

which improved the efficiency of methane production was determined as $30 \mathrm{~g} \mathrm{VSS} / \mathrm{L}$. At the first range namely butter concentration between $10 \mathrm{~g}$ VSS/L and $30 \mathrm{~g}$ VSS/L (Figure 4A), methane production increased compared to $0 \mathrm{~g} \mathrm{VSS} / \mathrm{L}$ chicken manure anaerobic digestion. Furthermore, methane production decreased rapidly above the addition of $30 \mathrm{~g} \mathrm{VSS} / \mathrm{L}$, almost 4 times higher than the value at $60 \mathrm{~g}$ VSS/L (Figure $4 \mathrm{~B}$ ), 3 to 8 times higher than the highest volume at $60 \mathrm{~g}$ VSS/L (anaerobic and OFR $0.13 \mathrm{~mL} / \mathrm{h}$ ), 10 times at $40 \mathrm{~g} \mathrm{VSS} / \mathrm{L}$ 


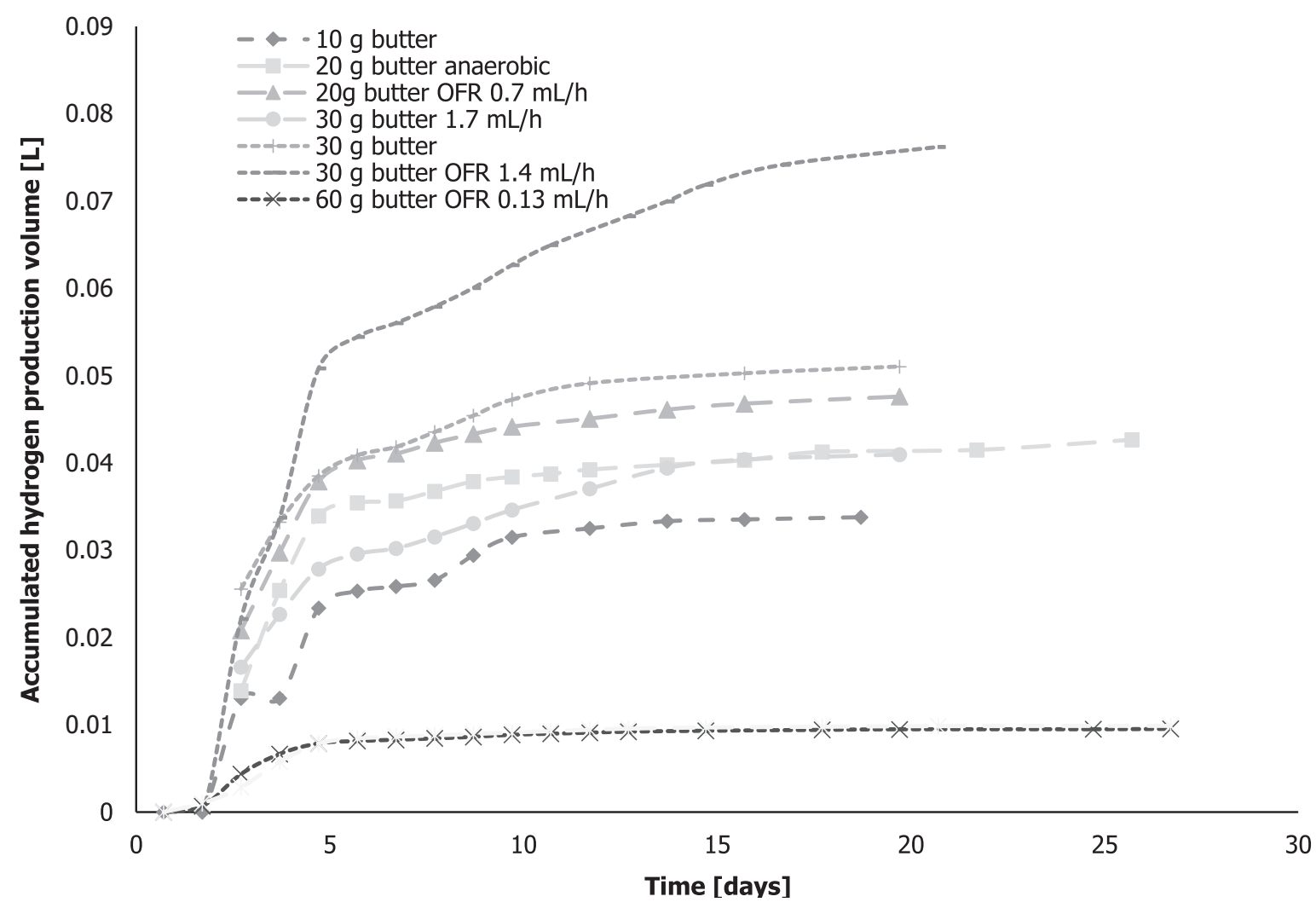

Figure 7A. Accumulated hydrogen production from chicken manure of $20 \mathrm{~g} \mathrm{VSS} / \mathrm{L}$ from different butter loads $\mathrm{g}$ VSS/L and oxygen flow rates

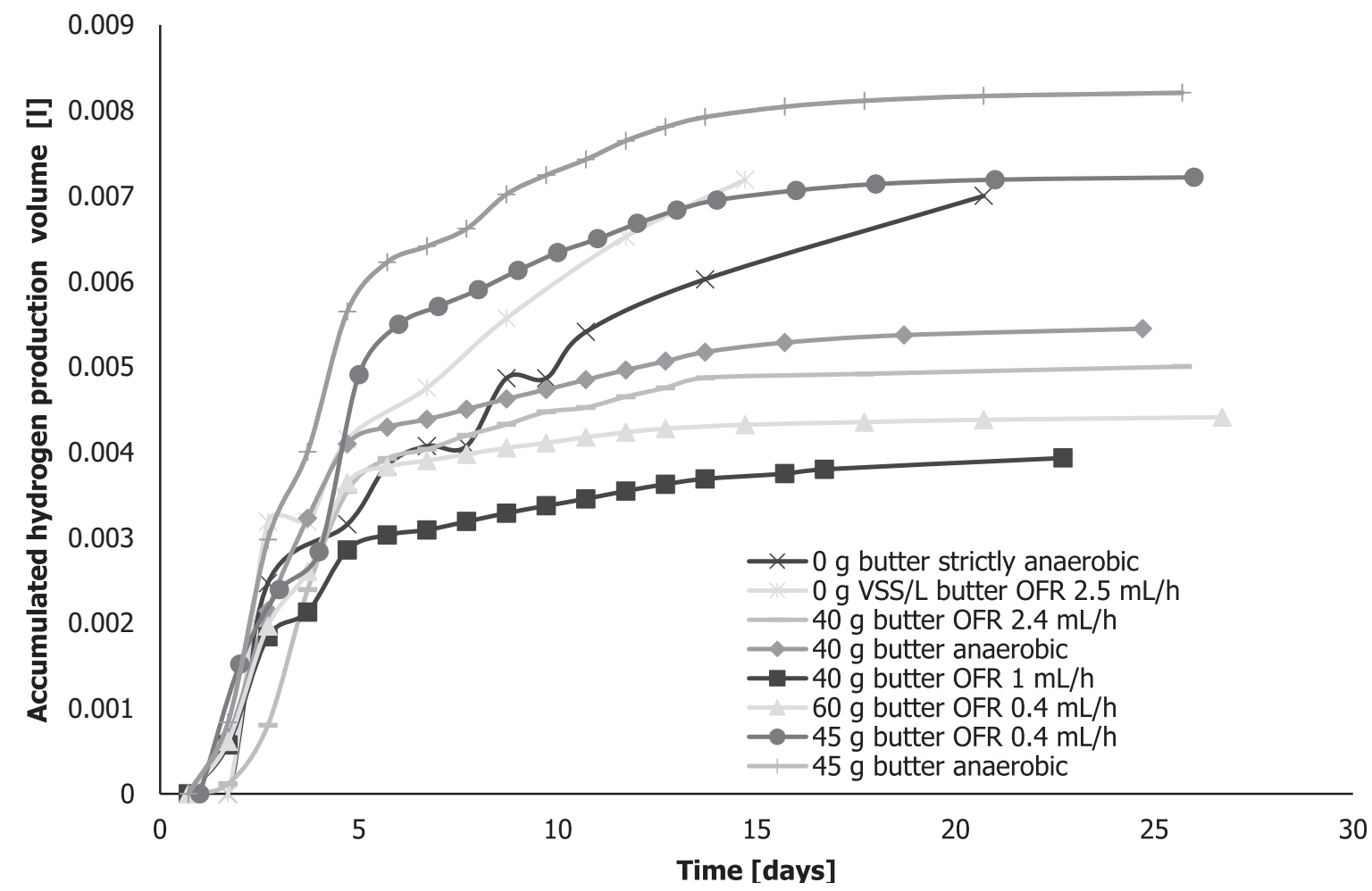

Figure 7B. Accumulated hydrogen production from chicken manure of $20 \mathrm{~g}$ VSS / $\mathrm{L}$ from different butter loads $\mathrm{g}$ VSS/L and oxygen flow rates. 


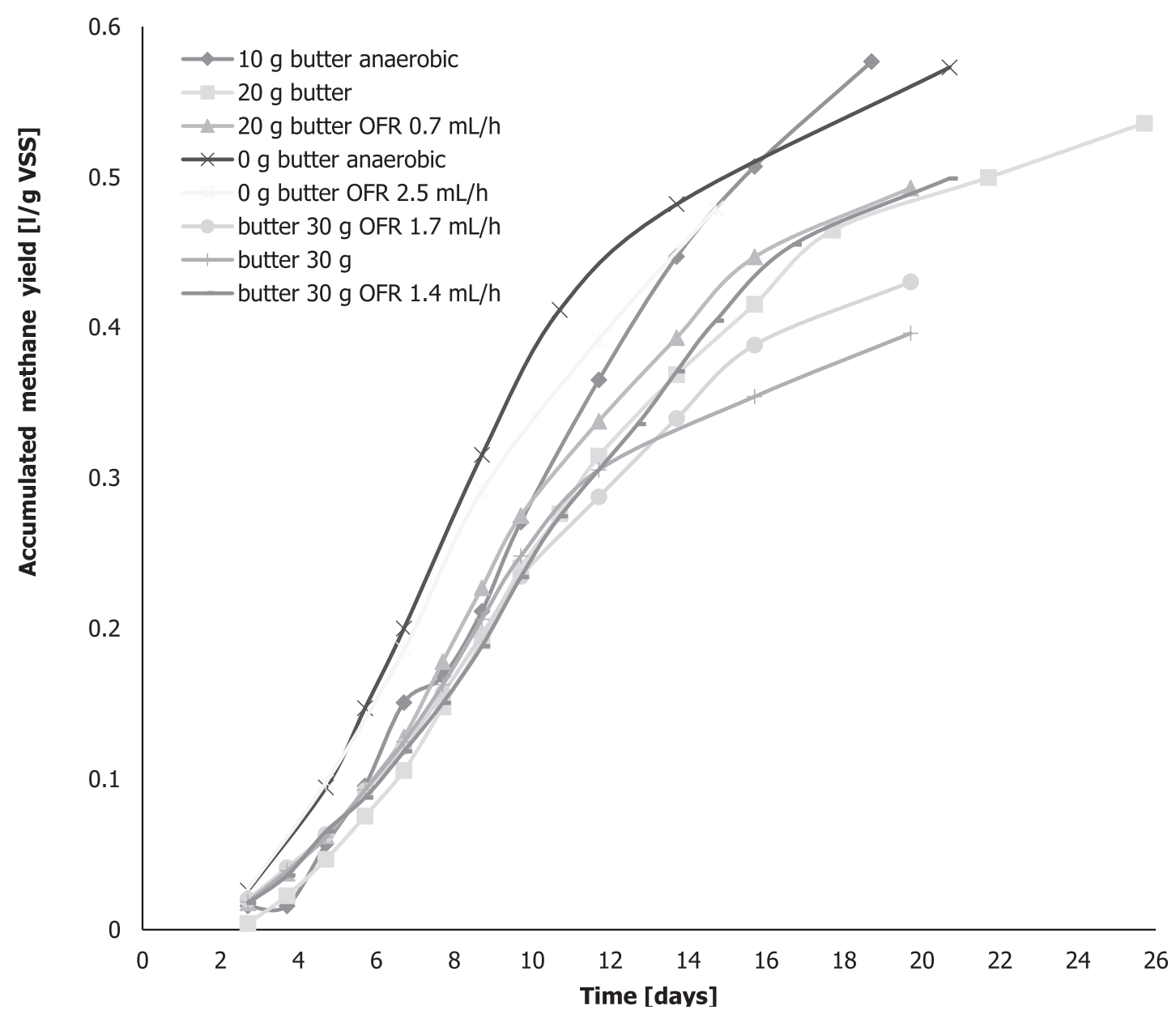

Figure 8A. Methane Yield from chicken manure of $20 \mathrm{~g} \mathrm{VSS} / \mathrm{L}$ from different butter loads $\mathrm{g}$ VSS/L and oxygen flow rates.

and OFR $2.4 \mathrm{~mL} / \mathrm{h}$, up to 250 times at $60 \mathrm{~g} \mathrm{VSS} / \mathrm{L}$ and OFR $0.4 \mathrm{~mL} / \mathrm{h}$. Moreover, $20 \mathrm{~g}$ VSS/L butter addition in strictly anaerobic conditions had 6 times higher biogas production similar to methane volume with $30 \mathrm{~g}$ VSS/L and OFR $1.7 \mathrm{~mL} / \mathrm{h}$. The high methane production at OFR $1.4 \mathrm{~mL} / \mathrm{h}$ butter $30 \mathrm{~g} \mathrm{VSS} / \mathrm{L}$ ( $25 \mathrm{~L}$ of methane) correlated with the reduction of volatile acids and ammonia. This was due to the high conversion of volatile acids to methane, while the process is enhanced by the reduction of ammonia (Andriani, et al. 2014). In the $40 \mathrm{~g}$ VSS/L and $1 \mathrm{~mL} / \mathrm{h}$, methane production decreased due to an increase in ammonia concentration. The addition of butter under strictly anaerobic conditions prolonged methane production by supplying more substrate but did not improve yield as shown Table 2 .

\section{Hydrogen Production Versus Hydrogen Sulfide Emission}

The gas analyzer showed the presence of hydrogen, methane, carbon dioxide, oxygen, nitrogen, and hydrogen sulfide. The hydrogen sulfide emission was lower than hydrogen production at a stable level under strict anaerobic condition at $0 \mathrm{~g}$ VSS/L (Figure $6 \mathrm{~A}$ and $7 \mathrm{~A}$ ), but increased with hydrogen production enhancement and the ratio was then stabilized after 5 days. After this period, the total hydrogen/hydrogen sulfide (Figures $5 \mathrm{~A}$ and $5 \mathrm{~B}$ ) ratio did not change due to micro-aeration and butter addition. Furthermore, the ratio was twice lower in butter addition from $10 \mathrm{~g}$ VSS/L to $30 \mathrm{~g}$ VSS/L compared to $0 \mathrm{~g}$ VSS/L and $40 \mathrm{~g}$ VSS/L with OFR $1 \mathrm{~mL} / \mathrm{h}$, meanwhile, this was caused by an increase in volatile acids concentration (figure 3 ). At $40 \mathrm{~g} \mathrm{VSS} / \mathrm{L}$, the smallest ratio was observed with a higher increase in ammonia (Figure 2). This showed that efficient hydrogen production correlates with a lowlevel of volatile acids and ammonia.

Figures 6 to 7 show that the decrease in volatile organic acid in the butter addition of $30 \mathrm{~g}$ VSS/L, was higher than hydrogen production. These results showed optimum values of butter addition ( $10 \mathrm{~g} \mathrm{VSS} / \mathrm{L}-30 \mathrm{~g}$ 


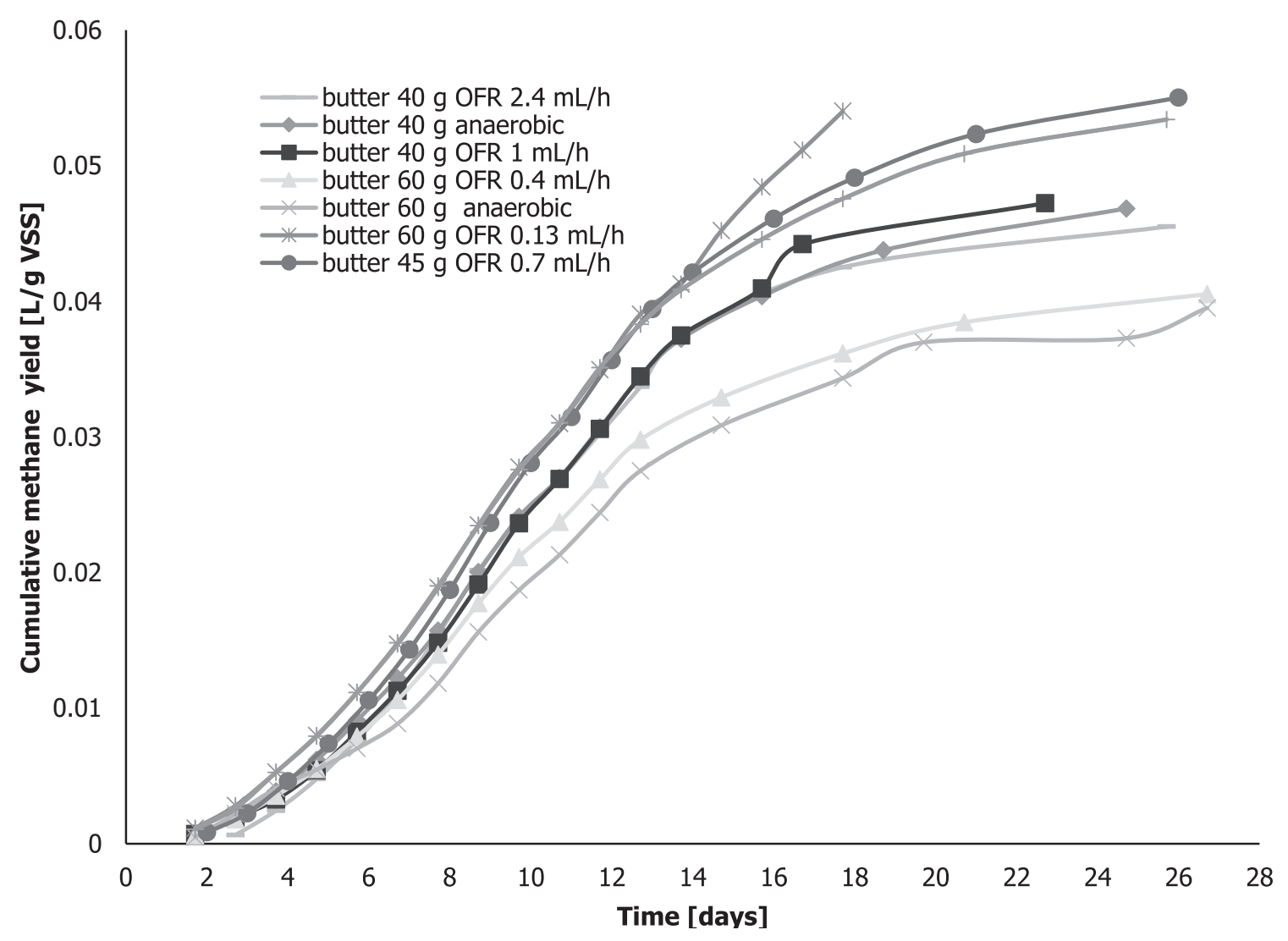

Figure 8B. Methane yield from chicken manure of $20 \mathrm{~g} \mathrm{VSS} / \mathrm{L}$ ats different butter loads $\mathrm{g}$ VSS/L and oxygen flow rates

VSS/L) to manure, with high hydrogen and methane production followed by ammonia and volatile acids reduction. The hydrogen production was slow up to 60 $\mathrm{g}$ VSS/L, where a slight increase was observed along with methane. At $30 \mathrm{~g} \mathrm{VSS} / \mathrm{L}$ and OFR $1.4 \mathrm{~mL} / \mathrm{h}$, the biogas mixture contained 60 to $74 \%$ methane, and $0.01 \%$ to $3 \%$ of hydrogen, while other treatments contained 60 to $70 \%$ methane and 0.5 to $3 \%$ of hydrogen. The hydrogen obtained is not converted in acetogenesis from the acidogenesis (DF) part. Based on the results, hydrogen production from chicken manure with or without butter correlates (Figure 7A and 7B) with hydrogen sulfide emission (Figure 6A and 6B).

A previous study showed that bacteria during hydrogen production decompose fats, sugars, and proteins (Edwiges et al., 2018). The protein was produced from the bacterial fermentation of chicken manure, while the hydrogen sulfide was obtained from the decomposition of proteins containing methionine and cysteine amino acids. Furthermore, the growth trend of hydrogen sulfide was identical to that of hydrogen production. The butter addition from $0 \mathrm{~g}$ VSS/L to $45 \mathrm{~g} \mathrm{VSS} / \mathrm{L}$ caused an increase in hydrogen sulfide emission. At $40 \mathrm{~g} \mathrm{VSS} / \mathrm{L}$, the hydrogen sulfide emission increased with significant changes in the volatile acids and ammonia concentration due to the decomposed proteins. Compared to $45 \mathrm{~g} \mathrm{VSS} / \mathrm{L}$, the addition of 60 $\mathrm{g}$ VSS/L in micro-aeration cases showed an increase in the accumulated hydrogen production. In addition, hydrogen sulfide emission grew with an increase in the added butter, but the ratios between accumulated hydrogen and hydrogen sulfide were still stable. These trends were not observed in previous publications of dark fermentation (Mechery, et al, 2019) or anaerobic digestion (Gallipoli et al., 2020). This is because the majority of samples from $A D$ and DF were only analyzed by gas chromatography (GC). In GC, both gases are observed periodically, but dependencies are not assumed. Simultaneous determination of hydrogen and hydrogen sulfide needs to combine different techniques of GC analysis.

\section{Biogas Component}

The overall discussion of results involving three biogas components is presented in Table 2. Based on the results, the trends of accumulated hydrogen 
and hydrogen sulfide volume differed significantly from methane This is shown by the high cumulative hydrogen and methane production which did not match with gas component yield. The methane yield decreased significantly with butter addition to chicken manure above $30 \mathrm{~g} \mathrm{VSS} / \mathrm{L}$ (Table 2). Meanwhile, the highest methane yield obtained in this study was smaller compared to (Budych-Gorzna et al., 2016) but higher than fat wastes in (Rafieenia et al., 2017). Furthermore, butter addition up to $30 \mathrm{~g} \mathrm{VSS} / \mathrm{L}$ was the limit after which methane yields significantly decreased 10 times compared to $0 \mathrm{~g} \mathrm{VSS} / \mathrm{L}$. At this concentration, hydrogen production increases and then rapidly declines. There was no observed shock load in wheat straw (Karapaju et al., 2009) but a rapid decrease of hydrogen yield was observed above this concentration. Moreover, methane yield slightly increased at $45 \mathrm{~g}$ VSS/L but then decreased rapidly. The micro-aeration growth reduced methane yield in most cases except at $45 \mathrm{~g}$ VSS/L with OFR $0.4 \mathrm{~mL} / \mathrm{h}$, while the most significant change in the hydrogen sulfide to hydrogen ratio occurred in the first 5 days with unstable growth of both components. This was then followed by a shift in the process from hydrogen to higher methane production (also called hydrogenotrophic AD) (Liu et al., 2020). These results show that volatile acids and ammonia reduction stimulate hydrogen yield and inhibit the emission of hydrogen sulfide. The butter addition increased the decomposition of proteins, which led to higher emission of hydrogen sulfide. Although the methane production decreased, the overall yield increased up to $30 \mathrm{~g} \mathrm{VSS} / \mathrm{L}$. With $30 \mathrm{~g} \mathrm{VSS} / \mathrm{L}$ and OFR $1.4 \mathrm{~mL} / \mathrm{h}$, the growth was similar for 16 days, this incidence of accumulated hydrogen is unusual with most cases of production (Yuan et al., 2019). Furthermore, the hydrogen sulfide emission trends were similar to hydrogen production but were 10 or more times lower. There was an increase with butter addition from 0 to $60 \mathrm{~g} \mathrm{VSS} / \mathrm{L}$, while the optimal conditions for hydrogen production were $30 \mathrm{~g}$ VSS/L butter addition with OFR $1.4 \mathrm{~mL} / \mathrm{h}$. The methane and hydrogen production was 10 days longer than observed for wheat straw and sour cabbage (Sołowski et al., 2020), while the micro-aeration reduced hydrogen sulfide emission (Pokorna-Krayzelova et al., 2018). As shown in Table 2, the length of biogas production depends on the ratio of butter and chicken manure. For samples treated with only chicken manure, the biogas production lasted 15 days, meanwhile, with $20 \mathrm{~g}$ VSS and OFR 0.7, the duration was 25 days. In the butter addition from 0 to $30 \mathrm{~g} \mathrm{VSS} / \mathrm{L}$ the digestion occurred for 19 days, meanwhile, at $30 \mathrm{~g} \mathrm{VSS} / \mathrm{L}$, the chicken manure to butter ratio of (2:3) and $1: 2$ (40 g VSS/L) prolonged the process to 21 and 23 days respectively. In addition, the $5 \mathrm{~g} \mathrm{VSS} / \mathrm{L}$, and $45 \mathrm{~g} \mathrm{VSS} / \mathrm{L}$ treatment (ratio manure $1: 2.5)$, enhanced the process to 26 days, while the 15 $\mathrm{g} \mathrm{VSS} / \mathrm{L}$ and $45 \mathrm{~g} \mathrm{VSS/L}$ (ratio manure 1:2.5), reduced the process to 25 days. Methane Yields were compared in Figure $8 \mathrm{~A}$ and $8 \mathrm{~B}$.

Figure $8 \mathrm{~A}$ shows that the methane yield ranged from $396 \mathrm{~mL} \mathrm{CH}_{4} / \mathrm{g}$ VSS to $577 \mathrm{~mL} \mathrm{CH}_{4} / \mathrm{g}$ VSS and the highest was found in the butter addition $0 \mathrm{~g}$ VSS/L. These results were higher than: cow manure with food wastes (butter mixture, palm oil, meat, and margarine ) with a ratio of $1: 8$ and $208.93 \mathrm{~mL} \mathrm{CH}_{4} / \mathrm{g}$ VSS (Sandriaty et al., 2018); lipid waste $1.67 \mathrm{~g}$ VSS/L (tuna $7.5 \%$, butter $22.3 \%$, apple $27 \%$, banana $27 \%$, chicken breast $7.5 \%$, bread $1.5 \%$, pasta $1.5 \%$, and minestrone soup $5.5 \%$ ) of $257 \mathrm{~mL} \mathrm{CH}_{4} / \mathrm{g} \mathrm{VSS}$; as well as protein waste $1.67 \mathrm{~g} \mathrm{VSS} / \mathrm{L}$ (tuna $31.1 \%$, butter $5.5 \%$, apple $7.85 \%$, banana $7.85 \%$, chicken breast $31.1 \%$, bread $3.2 \%$, pasta $3.2 \%$, minestrone soup $10.2 \%$ ) of 350 $\mathrm{mL} \mathrm{CH}_{4} / \mathrm{g}$ VSS (Rafieenia et al., 2017). However, these results were lower than in the case of chicken manure with waste activated sludge $1: 1$ of $880 \mathrm{~mL} \mathrm{CH}_{4} / \mathrm{g}$ VSS Budych-Gorzna et al., 2016). Hydrogen yields ranged from $0.36 \mathrm{~mL} \mathrm{H}_{2} / \mathrm{g}$ VSS to $1.54 \mathrm{H}_{2} \mathrm{~mL} / \mathrm{g}$ VSS in reverse order compared to methane yields.

The hydrogen yields obtained in this study were higher than glycerol $15 \mathrm{gVSS} / \mathrm{L}-0.002 \mathrm{~mL} \mathrm{H}_{2} / \mathrm{g}$ VSS (Paillet et al., 2019) but less than lipid waste $1.67 \mathrm{~g}$ VSS/L (tuna $7.5 \%$ butter $22.3 \%$, apple $27 \%$, banana $27 \%$, chicken breast $7.5 \%$, bread $1.5 \%$, pasta $1.5 \%$, minestrone soup $5.5 \%$ ) of $27.93 \mathrm{~mL} \mathrm{H}_{2} / \mathrm{g} \mathrm{VSS}$, and protein waste $1.67 \mathrm{~g} \mathrm{VSS} / \mathrm{L}$ (tuna $31.1 \%$ butter $5.5 \%$, apple $7.85 \%$, banana $7.85 \%$, chicken breast $31.1 \%$, bread $3.2 \%$, pasta $3.2 \%$, minestrone soup $10.2 \%$ ) $8.02 \mathrm{~mL} \mathrm{H}_{2} / \mathrm{g}$ VSS (Rafieenia et al., 2017).

\section{CONCLUSIONS}

The addition of butter improves anaerobic digestion in concentration from $10 \mathrm{~g} \mathrm{VSS} / \mathrm{L}$ to $30 \mathrm{~g} \mathrm{VSS} / \mathrm{L}$ by increasing the accumulation of gases namely hydrogen and methane. The optimal and limit concentration for methane and hydrogen production ranges from $30 \mathrm{~g}$ VSS/L to $20 \mathrm{~g} \mathrm{VSS/L}$. Above this concentration, only an increase in hydrogen sulfide emission was observed with a decrease in methane and hydrogen production except for butter addition $60 \mathrm{~g}$ VSS/L. Furthermore, the optimal condition for the anaerobic digestion of the substrates was $20 \mathrm{~g}$ VSS/L of chicken manure with $30 \mathrm{~g}$ VSS/L butter, and oxygen flow rate $1.7 \mathrm{~mL} / \mathrm{h}$ which produced $25 \mathrm{~L}$ of methane and $78 \mathrm{~mL}$ of hydrogen. This study showed that hydrogen sulfide emission is dependent on hydrogen production. Hydrogen sulfide emission increased with the addition of butter, while micro- 
aeration reduced ammonia and volatile organic acids appearance but improved the hydrogen and methane production. Moreover, butter addition up to $30 \mathrm{~g} \mathrm{VSS} / \mathrm{L}$ increased hydrogen yield along with hydrogen sulfide emission. Shock load using butter for chicken manure did not shift the process from methane to hydrogen production but lowered methane yield. The shift to hydrogen was observed with butter addition up to 30 $\mathrm{g}$ VSS/L but this phenomenon require further studies.

\section{ACKNOWLEDGEMENTS}

This study was funded by Provincial Fund for Environmental Protection and Water Management in Gdańsk under project no. RX-15/19/2017, the National Centre for Research and Development in Poland, under project no. BIOSTRATEG 3/344128/12/NCBR/2017 and the Institute of Fluid-Flow Machinery, Polish Academy of Science in Gdansk (grant number FBW-44 - Solowski).

\section{CONFLICT OF INTEREST STATEMENT}

The authors declare that there is no conflict of interest.

\section{REFERENCES}

Abouelenien, F., Nakashimada, Y., \& Nishio, N. (2009). Dry mesophilic fermentation of chicken manure for production of methane by repeated batch culture. JBIOSC, 107(3), 293-295. https://doi.org/10.1016/j.jbiosc.2008.10.009

Abu-Irmaileh, B., \& Abu-Rayyan, A. (2004). In-row Preplant Manure Composting Reduces Weed Populations. HortScience, 39(6), 1456-1460.

Alfa, I. M., Dahunsi, S. O., Iorhemen, O. T., Okafor, C. C., \& Ajayi, S. A. (2014). Comparative evaluation of biogas production from Poultry droppings, Cow dung and Lemon grass. Bioresource Technology, 157, 270-277. https://doi.org/10.1016/j.biortech.2014.01.108

Alsouleman, K., Linke, B., Klang, J., Klocke, M., Krakat, N., \& Theurl, S. (2016). Reorganisation of a mesophilic biogas microbiome as response to a stepwise increase of ammonium nitrogen ... PhD project View project. Bioresource Technology, 208(March), 200-204. https:// doi.org/10.1016/j.biortech.2016.02.104

Amanullah, M. M., Sekar, S., \& Muthukrishnan, P. (2010). Prospects and potential of poultry manure. Asian Journal of Plant Sciences, 9(4), 172-182. https://doi. org/10.3923/ajps.2010.172.182

Andrade, W. R., Xavier, C. A. N., Coca, F. O. C. G., Arruda, L. D. O., \& Santos, T. M. (2016). Biogas production from ruminant and monogastric animal manure co-digested with manipueira. Archivos de Zootecnia, (September).

Andriani, D., Wresta, A., Atmaja, T. D., \& Saepudin, A. (2014). $A$ review on optimization production and upgrading biogas through $\mathrm{CO} 2$ removal using various techniques. Applied Biochemistry and Biotechnology, 172(4), 19091928. https://doi.org/10.1007/s12010-013-0652-x

Anjum, R., Grohmann, E., \& Krakat, N. (2016). Anaerobic digestion of nitrogen rich poultry manure: Impact of thermophilic biogas process on metal release and microbial resistances Chemosphere, (November), 1-11. https://doi.org/10.1016/j.chemosphere.2016.11.132

Atasoy, M., \& Cetecioglu, Z. (2020). Bio-augmentation of mixed culture fermentation by Clostridium butyricum to enhance butyric acid production. Journal of Environmental Chemical Engineering, 8, pp 104496. Doi: 10.1016/j. jece.2020.104496

Atasoy, M., Owusu-Agyeman, I., Plaza, E., \& Cetecioglu, Z. (2018). Bio-based volatile fatty acid production and recovery from waste streams: Current status and future challenges. Bioresource Technology, 268, 773-786. https://doi.org/10.1016/j.biortech.2018.07.042

Billen, P., Costa, J., Van Der Aa, L., Van Caneghem, J., \& Vandecasteele, C. (2015). Electricity from poultry manure: A cleaner alternative to direct land application. Journal of Cleaner Production, 96, 467-475. https://doi. org/10.1016/j.jclepro.2014.04.016

Budych-Gorzna, M., Smoczynski, M., \& Oleskowicz-Popiel, P. (2016). Enhancement of biogas production at the municipal wastewater treatment plant by co-digestion with poultry industry waste. Applied Energy, 161, 387394. https://doi.org/10.1016/j.apenergy.2015.10.007

Bundhoo, M. A. Z., Mohee, R., \& Hassan, M. A. (2015). Effects of pre-treatment technologies on dark fermentative biohydrogen production: A review. Journal of Environmental Management, 157, 20-48. https://doi. org/10.1016/j.jenvman.2015.04.006

Chodová, D., \& Tůmová, E. (2020). Insects in chicken nutrition. A review, 18(X). https://doi.org/10.15159/AR.20.003

Domaszewicz, B., Kuliś, M., Figaj, H., Tylkowska-Siek, A., Wątroba, E., Dach-Oleszek, I., \& Wieczorkowski, R. (2016). Zwierzęta Gospodarskie w 2015 r. Warsaw. Retrieved from https://stat.gov.pl/files/gfx/ portalinformacyjny/pl/defaultaktualnosci/5508/6/16/1/ zwierzeta_gospodarskie_w_2015.pdf

Dreschke, G., Papirio, S., Sisinni, D. M. G., Lens, P. N. L., \& Esposito, G. (2019). Effect of feed glucose and acetic acid on continuous biohydrogen production by Thermotoga neapolitana. Bioresource Technology, 273(October 2018), 416-424. https://doi.org/10.1016/j.biortech.2018.11.040

Edwiges, T., Frare, L., Mayer, B., Lins, L., Mi Triolo, J., Flotats, X., \& de Mendonça Costa, M. S. S. (2018). 
Influence of chemical composition on biochemical methane potential of fruit and vegetable waste. Waste Management, 71, 618-625. https://doi.org/10.1016/j. wasman.2017.05.030

Fagbohungbe, M. O., Onyeri, C., Adewale, C., \& Semple, K. T. (2019). The effect of acidogenic and methanogenic conditions on the availability and stability of carbon, nitrogen and phosphorus in a digestate. Journal of Environmental Chemical Engineering, 7(3), 103138. https://doi.org/10.1016/j.jece.2019.103138

Gallipoli, A., Braguglia, C. M., Gianico, A., Montecchio, D., \& Pagliaccia, P. (2020). Kitchen waste valorization through a mild-temperature pretreatment to enhance biogas production and fermentability: Kinetics study in mesophilic and thermophilic regimen. Journal of Environmental Sciences (China), 89(February), 167179. https://doi.org/10.1016/j.jes.2019.10.016

Ganidi, N., Tyrrel, S., \& Cartmell, E. (2009). Anaerobic digestion foaming causes-A review. Bioresource Technology, 100(23), 5546-5554. https://doi.org/10.1016/j.biortech.2009.06.024

García, A. B., \& Cammarota, M. C. (2019). Biohydrogen production from pretreated sludge and synthetic and real biodiesel wastewater by dark fermentation. International Journal of Energy Research. https://doi. org/10.1002/er.4376

Hitit, Z. Y., Zampol Lazaro, C., \& Hallenbeck, P. C. (2017). Increased hydrogen yield and COD removal from starch/glucose based medium by sequential dark and photo-fermentation using Clostridium butyricum and Rhodopseudomonas palustris. International Journal of Hydrogen Energy, 42(30), 18832-18843. https://doi. org/10.1016/j.ijhydene.2017.05.161

Janczak, D., Malinska, K., Czekała, W., Cáceres, R., Lewicki, A., \& Dach, J. (2017). Biochar to reduce ammonia emissions in gaseous and liquid phase during composting of poultry manure with wheat straw, 66, 36-45. https:// doi.org/10.1016/j.wasman.2017.04.033

Kaparaju, P., Serrano, M., Thomsen, A. B., Kongjan, P., \& Angelidaki, I. (2009). Bioethanol, biohydrogen and biogas production from wheat straw in a biorefinery concept. Bioresource Technology, 100(9), 2562-2568. https://doi.org/10.1016/j.biortech.2008.11.011

Khoshnevisan, B., Tsapekos, P., Alfaro, N., Díaz, I., FdzPolanco, M., Rafiee, S., \& Angelidaki, I. (2017). A review on prospects and challenges of biological H2S removal from biogas with focus on biotrickling filtration and microaerobic desulfurization. Biofuel Research Journal, 4(4), 741-750. https://doi.org/10.18331/BRJ2017.4.4.6

Lami, M. (2016). Biogas Production from Co-Digestion of Poultry Manure and Orange Peel through Thermo- Chemical PreTreatments in Batch Fermentation, (4), 777-795.
Liu, C., Luo, G., Liu, H., Yang, Z., Angelidaki, I., O-Thong, S., Liu, G., Zhang S., Wang, W. (2020). CO as electron donor for efficient medium chain carboxylate production by chain elongation: Microbial and thermodynamic insights. Chemical Engineering Journal, 390(February), 124577. https://doi.org/10.1016/j.cej.2020.124577

Mechery, J., Thomas, D. M., Kumar, C. S. P., Joseph, L., \& Sylas, V. P. (2019). Biohydrogen production from acidic and alkaline hydrolysates of paddy straw using locally isolated facultative bacteria through dark fermentation. Biomass Conversion and Biorefinery. https://doi. org/10.1007/s13399-019-00515-0

Moriarty, K. (2013). Feasibility Study of Anaerobic Digestion of Food Waste in St. Bernard, Louisiana A Study Prepared in Partnership with the Environmental Protection Agency for the RE-Powering America 's Land Initiative : Siting Renewable Energy on Potentially Contaminat. National Renewable Energy Laboratory (NREL), (January), 1-51. https://doi.org/10.1016/S0961-9534

Murarka, A., Dharmadi, Y., Yazdani, S. S., \& Gonzalez, R. (2008). Fermentative utilization of glycerol by Escherichia coli and its implications for the production of fuels and chemicals. Applied and Environmental Microbiology, 74(4), 11241135. https://doi.org/10.1128/AEM.02192-07

Myszograj, S., \& Puchalska, E. (2012). Odpady z chowu i uboju drobiu - zagrożenie dla środowiska czy surowiec do produkcji energii Waste from rearing and slaughter of poultry - treat to the environment or feedstock for energy. Medycyna Środowiskowa, 1(3), 106-115.

Nguyen, D., \& Khanal, S. K. (2018). A little breath of fresh air into an anaerobic system: How microaeration facilitates anaerobic digestion process. Biotechnology Advances, 36(7), 1971-1983. https://doi.org/10.1016/j. biotechadv.2018.08.007

Nordmann, W. (1977). Die Überwachung der Schlammfaulung. KA-Informationen für das Betriebspersonal. Beilage Zur Korrespondenz Abwasser, 3/77, 77.

Ogundijo, D. S., Adetunji, M. T., Azeez, J. O., \& Arowolo, T. A. (2017). Integrated Fertilizer Management : Influence On Soil Nitrogen, Available Phosphorus, Potassium , Nutrient Uptake And ... Integrated Fertilizer Management : Influence on Soil Nitrogen, Available Phosphorus, Potassium,. Communications in Soil Science and Plant Analysis, 00(00), 1-12. https://doi.org/10.1080/001036 24.2017.1311909

Paillet, F., Marone, A., Moscoviz, R., Steyer, J. P., TapiaVenegas, E., Bernet, N., \& Trably, E. (2019). Improvement of biohydrogen production from glycerol in micro-oxidative environment. International Journal of Hydrogen Energy, 44(33), 17802-17812. https://doi. org/10.1016/j.ijhydene.2019.05.082 
Pokorna-Krayzelova, L., Vejmelková, D., Selan, L., Jenicek, P., Volcke, E. I. P., \& Bartacek, J. (2018). Final products and kinetics of biochemical and chemical sulfide oxidation under microaerobic conditions. Water Science and Technology, 78(9), 1916-1924. https://doi.org/10.2166/ wst.2018.485

Rafieenia, R., Girotto, F., Peng, W., Cossu, R., Pivato, A., Raga, R., \& Lavagnolo, M. C. (2017). Effect of aerobic pretreatment on hydrogen and methane production in a twostage anaerobic digestion process using food waste with different compositions. Waste Management, 59, 194199. https://doi.org/10.1016/j.wasman.2016.10.028

Sandriaty, R., Priadi, C., Kurnianingsih, S., \& Abdillah, A. (2018). Potential of biogas production from anaerobic co-digestion of fat, oil and grease waste and food waste. E3S Web of Conferences, 67, 1-5. https://doi. org/10.1051/e3sconf/20186702047

Sluiter, A., Hames, B., Hyman, D., Payne, C., Ruiz, R., Scarlata, C., ... Wolfe, J. (2008). Determination of total solids in biomass and total dissolved solids in liquid process samples. National Renewable Energy Laboratory (NREL), (March), 3-5. bagian ... ditulis lengkap

Słupek, E., Kucharska, K., \& Gębicki, J. (2019). Alternative methods for dark fermentation course analysis. $S N$ Applied Sciences, 1(5), 1-8. https://doi.org/10.1007/ s42452-019-0488-2

Sołowski, G., Hrycak, B., Czylkowski, D., Cenian, A., \& Pastuszak, K. (2018). Oxygen sensitivity of hydrogenesis ' and methanogenesis'. In Pikoń Krzysztof (Ed.), Contemporary Problems of Power Engineering and Environmental Protection 2017 (1st ed., pp. 157-159). Gliwice: Department of Technologies and Installations for Waste Management. https://doi.org/http://cleanalternative.eu/ wp-content/uploads/2018/01/Merged_OSWE_book.pdf

Sołowski, G., Hrycak, B., Czylkowski, D., Konkol, I., Pastuszak, K., \& Cenian, A. (2019). Hydrogen and Methane Production Under Conditions of Dark Fermentation Process with Low Oxygen Concentration. In K. Jibin, N.
Kalarikkal, S. Thomas, \& A. Nzihou (Eds.), Re-Use and Recycling of Materials Solid Waste Management and Water Treatment (1st ed., pp. 263-272). Gistrup: River Publisher.

Suchowska-Kisielewicz, M. (2014). Testing of Co-Fermentation of Poultry Manure and Corn Silage. Civil and Environmental Engineering Reports, 13(January 2014), 31-47. https:// doi.org/10.2478/ceer-2014-0013

Tang, G.-L., Huang, J., Sun, Z.-J., Tang, Q.-Q., Yan, C.-H., \& Liu, G.-Q. (2008). Biohydrogen production from cattle wastewater by enriched anaerobic mixed consortia: influence of fermentation temperature and $\mathrm{pH}$. Journal of Bioscience and Bioengineering, 106(1), 80-87. https://doi.org/10.1263/jbb.106.80

Theuerl, S., Klang, J., \& Prochnow, A. (2019). Process disturbances in agricultural biogas production-causes, mechanisms and effects on the biogas microbiome: A review. Energies, 12(3). https://doi.org/10.3390/en12030365

Toledo-Alarcón, J., Capson-Tojo, G., Marone, A., \& Paillet, F. (2017). Basics of bio-hydrogen production by dark fermentation. In Bioreactors for Microbial Biomass and Energy Conversion (pp. 199-220).

Trchounian, K., \& Trchounian, A. (2015). Hydrogen production from glycerol by Escherichia coli and other bacteria: An overview and perspectives. Applied Energy, 156, 174184. https://doi.org/10.1016/j.apenergy.2015.07.009

Yuan, T., Bian, S., Ko, J. H., Wu, H., \& Xu, Q. (2019). Enhancement of hydrogen production using untreated inoculum in twostage food waste digestion. Bioresource Technology, 189-196. https://doi.org/10.1016/j.biortech.2019.03.020

Zhang, J., Zhang, R., Wang, H., \& Yang, K. (2020). Direct interspecies electron transfer stimulated by granular activated carbon enhances anaerobic methanation efficiency from typical kitchen waste lipid-rapeseed oil. Science of the Total Environment, 704 (70), 135282 https://doi.org/10.1016/j.scitotenv.2019.13528 